\title{
USE OF TRICAINE METHANESULFONATE (MS-222) TO INDUCE ANAESTHESIA IN PUNTIUS DENISONII (DAY, 1865) (TeleOSTEI: CYPRINIFORMES: CYPRINIDAE), A THREATENED BARB OF THE WESTERN GHATS, INDIA
}

ISSN

Online 0974-7907 Print 0974-7893

T.V. Anna Mercy ${ }^{1}$, V. Malika ${ }^{2} \&$ S. Sajan ${ }^{3}$

OPEN ACCESS

${ }^{1,3}$ Faculty of Fisheries, College of Fisheries, Kerala University of Fisheries and Ocean Studies (KUFOS), Panangad, Ernakulam, Kerala 682506, India

${ }^{2}$ Faculty of Management Studies, College of Fisheries, Kerala University of Fisheries and Ocean Studies (KUFOS), Panangad, Ernakulam, Kerala 682506, India

${ }^{1}$ annamercy2002@yahoo.co.in, ${ }^{2}$ malikaramankutty@gmail.com, ${ }^{3}$ sajanpolayil@gmail.com (corresponding author)

Abstract:Anaesthesia is essential to minimizestressand physicaldamage during handling of fish in captivity. In the present study, induction time in Puntius denisonii (Day, 1865), an endangered aquarium fish exposed to four concentrations of MS-222 (50 mg L-1, $100 \mathrm{mg} \mathrm{L}^{-1}, 150$ $\mathrm{mg} \mathrm{L}^{-1}$ and $200 \mathrm{mg} \mathrm{L}^{-1}$ ) was determined. MS-222 appears to be highly effective as an anaesthetic with no side effects to both fish as well as humans. An induction time of less than or equal to three minutes, and a complete recovery in five minutes was used a basis to record the anaesthesia stages for different doses. The onsets of individual phases of anaesthesia and recovery stages were also studied. Concentration of $150 \mathrm{mg} \mathrm{L}^{-1}$ (induction $165 \pm 10$ seconds and recovery time $112 \pm 10$ seconds) was determined as the lowest concentration that induces anaesthesia in $P$. denisonii in less than three minutes. Induction and recovery times were dose-dependent. An inversely proportional relationship was observed between concentrations of anaesthetic and induction time. This is the first study to investigate the efficacy of different concentrations of MS-222 in Puntius denisonii and will be helpful to develop standardised techniques for transportation, captive breeding and other ex-situ conservation plans for this endangered and endemic barb.

Keywords: Anaesthetic, handling, MS-222, Puntius denisonii, Redlined Torpedo Barb.
Anaesthetics in ichthyological research greatly facilitate procedures including induction of spawning, obtaining body length/weight, conducting gonadal biopsies and transportation. Anaesthesia and sedation is usually essential to minimize stress and physical damage during handling of fish for routine husbandry operations (Summerfelt \& Smith 1990; Iwama et al. 1997; Ross \& Ross 1999). Commonly used anaesthetics in fishes include MS-222, benzocaine, quinaldine, chlorobutanol, phenoxyethanol and metomidate.

A number of considerations should be taken care of when choosing an anaesthetic including its efficacy, cost, availability, ease of use, and side effects on fish, humans and the environment (Marking \& Meyer 1985; Gilderhus \& Marking 1987; Mylonas et al. 2005). Overdose of an anaesthetic or retaining the fish in an anaesthetic bath for too long leads to the fading of ventilation, hypoxia, and finally, respiratory and cardiac collapse (Tytler \& Hawkins 1981). The fading of ventilation is an important warning sign suggesting that the exposure should be

DOI: http://dx.doi.org/10.11609/JoTT.03294.4414-9

Editor: Rajeev Raghavan, St. Albert's College, Kochi, India.

Date of publication: 26 May 2013 (online \& print)

Manuscript details: Ms \# 03294 | Received 06 August 2012 | Final received 19 April 2013 | Finally accepted 03 May 2013

Citation: Mercy, T.V.A., V. Malika \& S. Sajan (2013). Use of tricaine methanesulfonate (MS-222) to induce anaesthesia in Puntius denisonii (Day, 1865) (Teleostei: Cypriniformes: Cyprinidae), a threatened barb of the Western Ghats, India. Journal of Threatened Taxa 5(9): 4414-4419; http://dx.doi.org/10.11609/JoTT. 03294.4414-9

Copyright: (C) Mercy et al. 2013. Creative Commons Attribution 3.0 Unported License. JoTT allows unrestricted use of this article in any medium, reproduction and distribution by providing adequate credit to the authors and the source of publication.

Funding: Marine Products Export Development Authority, Kochi, India.

Competing Interest: None.
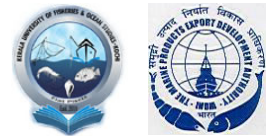

Acknowledgements: This research is carried out as a part of the Marine Products Export Development Authority (MPEDA) funded Project entitled, "Stock assessment and development of captive breeding technology of Puntius denisonii endemic indigenous ornamental fish of Western Ghats of India". Thanks are due to anonymous reviewers for their criticisms which improved the quality of the manuscript 
terminated (Hajek \& Klyszejko 2004; Dziaman et al. 2005).

Tricaine methanesulfonate (MS-222) is one of the most widely used anaesthetics in fish research and husbandry (Ross \& Ross 1999). MS-222 is a benzocaine derivative that is absorbed across the gills, bio transformed in the liver and probably kidney, and cleared primarily through the gills, with additional metabolites eliminated in urine and bile (Maren et al. 1968; Harms 1999). Several studies have evaluated the efficacy of MS-222 in various fish species (Roubach et al. 2001; Walsh \& Pease 2002; Iversen et al. 2003; King et al. 2005; Mylonas et al. 2005; Hajek et al. 2006; Pramod et al. 2010; Pawar et al. 2011).

Puntius denisonii (Teleostei: Cypriniformes: Cyprinidae) popularly known as the Red-lined Torpedo Barb or Miss Kerala (Image 1) is a small to medium sized barb endemic to the rivers flowing through the Western Ghats. The species is much sought after in the international ornamental fish trade and contributes to around $60 \%$ of India's ornamental fish exports (Mittal 2009). However, due to indiscriminate exploitation from the wild, the species is listed as Endangered in the IUCN Red List of Threatened Species (Ali et al. 2011).

Captive breeding is considered to be one of the solutions for ensuring sustainability and conserving wild populations of endangered species (Fraser 2008). Although $P$. denisonii is well adapted to captive conditions (Mercy 2009), it is very sensitive to handling and transportation, which frequently results in high mortality (Ramachandran et al. 2005).

Efforts to develop captive breeding technology for $P$. denisonii have revealed that the species is very difficult to handle for artificial propagation (Mercy et al.

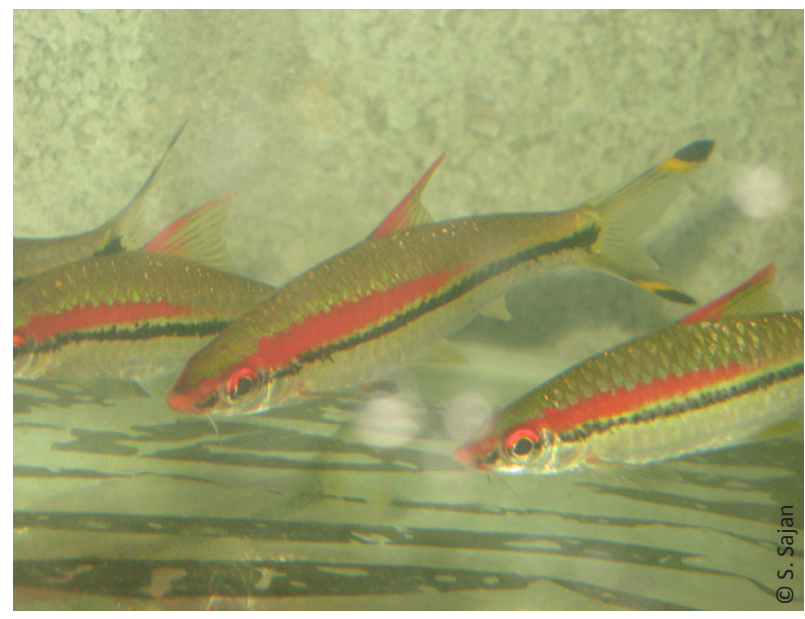

Image 1. Red-lined Torpedo Barb Puntius denisonii
2010). When handled out of water, fish were observed to experience stress, often leading to death within a very short period. Therefore, attempts were made to use anaesthetics to handle the fish during captive breeding. Using clove oil, handling stress was minimized and $P$. denisonii was bred successfully under hatchery conditions (Sajan et al. 2012).

In the present paper, we determine the effective concentration of Tricaine methanesulfonate (MS-222) that can be used as an anaesthetic for $P$. denisonii during captive breeding.

\section{Materials and Methods}

Experimental animals:Twenty individuals of captive bred $P$. denisonii (Image 1 ) of uniform age (approximately two years old) and mean weight of $16.5 \pm 3.5 \mathrm{~g}$ (13.0$20.0 \mathrm{~g}$ ) were used for the study. Prior to starting the experiment, fish were reared in outdoor cement tanks (2000L) for a period of 14 days to get acclimatized with the controlled rearing conditions. Water quality conditions such as temperature, $\mathrm{pH}$, alkalinity, hardness and ammonia were monitored and maintained within a narrow range of values. A photoperiod of 12L: 12D cycle (light period from $06.00-18.00 \mathrm{hr}$ ) was maintained throughout the duration of the experiment. Fish were fed with a commercial formulated diet with crude protein $(38 \%)$, crude fat $(4.0 \%)$, crude fibre $(3.0 \%)$, ash $(16 \%)$ and moisture (11\%) twice a day $(09.00$ and 17.00 $\mathrm{hr}$ ). All fish were healthy prior to, and throughout the duration of the study.

Anaesthetic: Tricaine methanesulfonate (MS-222) (Argent Laboratories, Redmond WA, United States of America) was used as the anaesthetic agent. MS-222 is an isomer of benzocaine with the amine group in the meta position of the benzene ring rather than the para position. MS-222 was solubilised in deionized water and buffered with sodium bicarbonate, using a ratio of 1:1 (sodium bicarbonate: MS-222), providing a final concentration of $10 \mathrm{mg} \mathrm{mL}^{-1}$ ( $\left.\mathrm{pH} 7.4\right)$. MS-222 dissolves well in water and was therefore added directly to the anaesthetic bath.

Experiment design: The experiment was carried out at the indigenous fish breeding hatchery of the Kerala University of Fisheries and Ocean Studies, Panangad, Ernakulam, Kerala (India), where techniques for the standardization of captive breeding and larval rearing of P. denisonii are being standardised (Mercy et al. 2010; Sajan et al. 2011). Preliminary studies were conducted to evaluate the effect of MS-222 on the behaviour and anaesthetic performance on $P$. denisonii. Dosages of anaesthesia for various teleosts provided in Weber et 
al. (2009) were used as base information and different concentrations of MS-222 (50 mg L $\mathrm{m}^{-1}, 100 \mathrm{mg} \mathrm{L}^{-1}, 150 \mathrm{mg}$ $\mathrm{L}^{-1}$ and $200 \mathrm{mg} \mathrm{L}^{-1}$ ) were selected for the experiment. Each concentration was added to the experiment tank five minutes before the introduction of fish (Charoendat et al. 2009). Both treatment and recovery water were taken from the tank, where the fish were maintained and both bath systems were aerated throughout the procedure. Water quality parameters monitored are listed in Table 1. During the experiment, a number of guidelines recommended by Hicks (1989) were followed.

Measures of anaesthesia: Stages of anaesthetization include induction, maintenance and recovery. A maximum duration from initial anaesthetic exposure to induction (stage IV) and the induction stage achieved usually depends on the dose and the length of exposure. Generally, an ideal anesthetic should produce anesthesia rapidly (e.g., less than 3 or 5 min), allow a speedy recovery, not be toxic to fish and users, leave low tissue residues and be inexpensive (Marking \& Meyer 1985; Gilderhus \& Marking 1987). The anaesthetic induction time is the period from the time when an experimental fish is placed in the anaesthetic tank until the time it does not respond to external stimuli. The recovery time is the period from the time when an anaesthetized fish is placed in a recovery tank until it recovers from anaesthetization with full equilibrium motion. Initial recovery time may vary from a few seconds to minutes, depending on the anaesthetic administered. The lowest effective concentration is the concentration that produces general anaesthesia within three minutes and allows the recovery within 10 minutes (Gilderhus 1990; Weyl et al. 1996). An induction time of three minutes or less with complete recovery in five minutes suggested by Marking \& Meyer (1985) was used to record the anaesthesia-induction stages for different dosages presented in this experiment (Table 2).

Table 1. Water Quality parameters in the experimental tanks

\begin{tabular}{|l|c|}
\hline Parameters & Values \\
\hline $\mathrm{pH}$ & $7.0 \pm 0.3$ \\
\hline Alkalinity $\left(\mathrm{mg} \mathrm{L}^{-1}\right)$ & $65 \pm 8.0$ \\
\hline Hardness $\left(\mathrm{mg} \mathrm{L}^{-1}\right)$ & $70 \pm 5.0$ \\
\hline Dissolved Oxygen $\left(\mathrm{mg} \mathrm{L}^{-1}\right)$ & $6.5 \pm 0.5$ \\
\hline Temperature (OC) & $27 \pm 0.5$ \\
\hline Nitrite $\left(\mathrm{mg} \mathrm{L}^{-1}\right)$ & $<0.01$ \\
\hline Total ammonia $\left(\mathrm{mg} \mathrm{L}^{-1}\right)$ & $<0.00$ \\
\hline
\end{tabular}

Experimental procedure: Each fish was randomly assigned to a particular anaesthetic concentration. Water used for the experiment was obtained from the same water system used in the tanks in which the fish were held prior to the experiment. The fish was then placed in $2 \mathrm{~L}$ experimental water bath equipped with an air stone and the stages of anaesthesia were recorded. When fish reached stage IV of anaesthesia (complete lack of voluntary movement), they were removed from the anaesthetic bath and returned to the recovery tank. Experiments were repeated four times. The induction and recovery times were measured using an electronic stopwatch (Casio India). Each fish was subjected to monitoring for any behavioural and/or health related changes for another seven days.

Post-treatment mortality: After the experiment, fish were transferred to circular cement tanks kept in outdoor facility (1000L) for seven days to assess the post recovery mortality (Bambang 2003; Charoendat et al. 2009; Pawar et al. 2011). During the post-treatment period, $50 \%$ of the tank water was exchanged daily and the fish were fed twice a day ad libitum with the commercial formulated feed given during pre-anaesthetic maintenance.

Data analysis: One way ANOVA was used to explain the significance between dosage and induction time, as well as dosage and recovery time. Induction time of anaesthesia was recorded as the interval from initial exposure to the anaesthetic, until the end of anaesthesia (stage IV). Duration for each recovery stage was also recorded, as the interval from reintroduction of the fish to the recovery tank. All data were reported as mean \pm S.D. Significant difference was tested at $95 \%$ confidence interval, represented as $\mathrm{P}<0.05$. The results were processed and analysed with the SPSS (Windows, Version 15.0).

\section{Results}

The induction time of Puntius denisonii decreased with increasing concentrations of MS-222. The induction time was less than three minutes for a dose of $150 \mathrm{mg} \mathrm{L}^{-1}$ and therefore this was considered as the best effective concentration of MS-222 for the induction of anaesthesia in P. denisonii. At $150 \mathrm{mg} \mathrm{L}^{-1}$, the time to reach a complete anesthesia (stage IV) $(165 \pm 10$ seconds) was significantly different $(P<0.05)$ from the other dosages $(50,100$ and $200 \mathrm{mg} \mathrm{L}^{-1}$ ) (Table 3). At lower concentrations (50 $\mathrm{mg} \mathrm{L}^{-1}$ and $\left.100 \mathrm{mg} \mathrm{L}^{-1}\right)$, more time (746 \pm 56 seconds and $506 \pm 20$ seconds) was required to reach stage I and stage IV, respectively.

There was a clear linear pattern of decreasing induction time with increasing concentration of the 
Table 2. Stages of anaesthetic induction (after Bowser 2001)

\begin{tabular}{|c|l|l|}
\hline Stages & Descriptor & General Behaviour response of fish \\
\hline 0 & Normal & Reactive to external stimuli; opercular rate and muscle tone normal \\
\hline I & Light sedation & Slight loss of reactivity to external stimuli; opercular rate slightly decreased; equilibrium normal \\
\hline II & Deep sedation & Total loss of reactivity to all but strong external stimuli; Slight decrease in opercular rate; equilibrium normal \\
\hline III & Partial loss of equilibrium & $\begin{array}{l}\text { Partial loss of muscle tone; swimming erratic; increased opercular rate; reactivity only to strong tactile and vibration } \\
\text { stimuli }\end{array}$ \\
\hline IV & Total loss of equilibrium & Total loss of muscle tone and equilibrium; slow but regular opercular rate; loss of spinal reflexes \\
\hline V & Medullary collapse & Respiratory movement ceases \\
\hline
\end{tabular}

anaesthetic, with the longest induction times for fish in the group exposed to $100 \mathrm{mg} \mathrm{L}^{-1}$ of MS-222 (506 \pm 20 seconds) and the shortest for fish exposed to $200 \mathrm{mg} \mathrm{L}^{-1}$ ( $97 \pm 5$ seconds). Induction times generally decreased significantly with increasing doses for MS-222 (Fig. 1).

The induction and recovery stages at different concentrations of the MS-222 showed significant differences $(P<0.05)$. Induction time decreased with increasing concentration of $\mathrm{MS}-222 \quad(\mathrm{P}<0.05)$. All fish subjected to the experiment recovered within three minutes. Recovery times increased with increasing concentrations of $\mathrm{MS}-222(\mathrm{P}<0.05)$. At higher concentrations the time taken to reach stage IV decreased, but the recovery time was extended. The study on induction times in terms of fish weight was conducted on 20 fish weighing between 13.0-20.0 g. No significant correlation was observed between induction times and weight of the fish $(P>0.05)$. The recovered, $P$. denisonii that were observed in the post- treatment period of seven days did not show any abnormal behaviour and/or mortality.

\section{Discussion}

The definition of efficacy with regard to anaesthetics is more or less subjective (Gilderhus \& Marking 1987).
Table 3. Timing (seconds) of anaesthesia and recovery phases in Puntius denisonii exposed to various MS-222 concentrations (mean \pm S.D)

\begin{tabular}{|l|c|c|c|c|}
\hline Stages of anaesthesia & \multicolumn{4}{|c|}{ MS 222 concentrations [mg L-1] } \\
\hline & 50 & 100 & 150 & 200 \\
\hline Light sedation (I) & $746 \pm 56$ & $59 \pm 4$ & $16 \pm 1$ & $10 \pm 1$ \\
\hline Deep sedation(II) & --- & $192 \pm 5$ & $46 \pm 2$ & $31 \pm 2$ \\
\hline Partial loss of equilibrium (III) & --- & $318 \pm 8$ & $122 \pm 7$ & $57 \pm 4$ \\
\hline Total loss of equilibrium (IV) & --- & $506 \pm 20$ & $165 \pm 10$ & $97 \pm 5$ \\
\hline Recovery time & $42 \pm 5$ & $84 \pm 6$ & $114 \pm 6$ & $154 \pm 7$ \\
\hline
\end{tabular}

Because stress responses vary widely between species, it is often necessary to screen dosages of different anaesthetic agents for each cultured species (Ross \& Ross 1999). MS-222 is a water soluble anaesthetic and the only one approved for use on fish in the United States (Pramod et al. 2010). This study demonstrated that MS-222 is efficient in anaesthetizing $P$. denisonii, an important freshwater fish species in the pet trade.

Induction times decreased significantly with the increase in anaesthetic concentration $(P<0.05)$, which are consistent with previous studies in teleost fishes (Mattson \& Riple 1989; Hseu et al. 1998; Mylonas et al. 2005; Gullian \& Villanueva 2009; Weber et al. 2009;
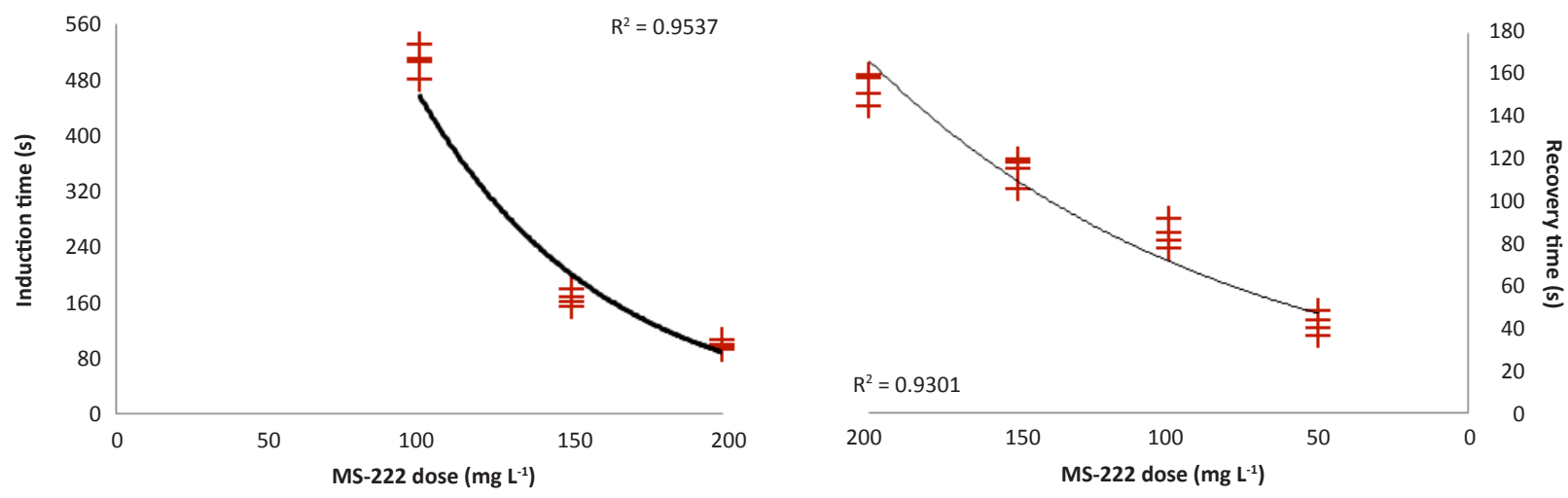

Figure 1. Induction time and recovery time in relation to MS-222 concentrations $\left(\mathrm{mg} \mathrm{L}^{-1}\right)$ in Puntius denisonii $(\mathrm{P}<0.05, \mathrm{n}=\mathbf{2 0})$ 
Heo \& Shin 2010; Pramod et al. 2010; Pawar et al. 2011; Sajan et al. 2012). The effective concentration of MS222 causing anaesthesia to $P$. denisonii was $150 \mathrm{mg} \mathrm{L}^{-1}$, similar to the observations made by Pawar et al. (2011) in Hippocampus kuda (175 $\mathrm{mgL}^{-1}$ and Donald et al. (2009) in Oreochromis niloticus (100-200 $\left.\mathrm{mg} \mathrm{L}^{-1}\right)$ Cyprinus carpio and Carrassius auratus (60-300 $\left.\mathrm{mgL}^{-1}\right)$, but higher than those obtained for temperate species such as Salmo gairdneri, Cyprinus carpio and Pimephales promelas (50-100 $\mathrm{mg} \mathrm{L}^{-1}$ ) by Ross \& Ross (1999), and Sylvester \& Holland (1982). Puntius denisonii exposed to $50 \mathrm{mg} \mathrm{L}^{-1}$ of MS-222 reached stage 1 in a maximum time of $746 \pm 56$ seconds, indicating that none of the fish exposed to this concentration of MS-222 was induced. Similar results were reported by Sladky et al. (2001) in Piaractus brachypomus. Overall, the concentration of anaesthetic to induce fish varies with the concentration of chemical required to bring them to a given level of anaesthesia, their tolerance of a given chemical and their recovery time (Summerfelt \& Smith 1990).

Statistical analysis showed that the time of induction and recovery of $P$. denisonii at different concentrations of MS-222 differ significantly $(P<0.05)$. All fishes used in the experiment recovered within three minutes. We observed that if the exposure time was prolonged, the recovery also becomes extended. Similar observations were made by Grzegorz et al. (2006) on Cyprinus carpio L. and Inoue et al. (2003) on juveniles of matrinxa Brycon cephalus. Prolonged recovery time with increased anaesthetic dosage has been reported in seven species of tropical reef teleosts (Cunha \& Rosa 2006), Oncorhynchus nerka (Woody et al. 2002), Rachycentron canadum (Gullian \& Villanueva 2009) and Dawkinsia filamentosus (Pramod et al. 2010).

The effective dose of MS-222 for Puntius denisonii is $150 \mathrm{mg} \mathrm{L}^{-1}$. This dosage induced the fish through all stages of anaesthesia, without any mortality. Further studies on the effects of anaesthetics on the haematological profile will considerably advance our understanding of anaesthesia in the husbandry of this threatened and endemic freshwater fish.

\section{REFERENCES}

Ali, A., N. Dahanukar \& R. Raghavan (2011). Puntius denisonii. In IUCN 2012. IUCN Red List of Threatened Species. Version 2012.1. <www.iucnredlist.org>. Downloaded on 20 September, 2012.

Bambang, H. (2003). Application of clove oil as anaesthetic for sea bass (Lates calcarifer, Bloch). MSc Thesis. Department of Aquaculture, Kasetsart University, 83pp.

Bowser, P.R. (2001). Anesthetic options for fish. In: Gleed, R.D. \& J.W. Ludders (eds.). Recent Advances in Veterinary Anesthesia and Analgesia: Companion Animals. International Veterinary Information
Service, New York, USA (available at http://www.ivis.org, Document no. A1412.0701)

Charoendat, U., N. Areechon, P. Srisapoome \& D. Chantasart (2009). Efficacy of synthetic eugenol as an anesthetic for Nile Tilapia (Oreochromis niloticus Linn.). Kasetsart Journal of Natural Science 43: $132-140$.

Cunha, F.E.A \& I.L. Rosa (2006). Anaesthetic effects of clove oil on seven species of tropical reef teleosts. Journal of Fish Biology 69: 1504-1512; http://dx.doi.org/10.1111/j.1095-8649.2006.01213.x

Dziaman, R., B. Klyszejko \& G. Hajek (2005). The effects of MS-222 on the cardiac and respiratory function and behaviour of common carp, Cyprinus carpio L., during general anaesthesia. Acta Ichthyologica et Piscatoria 35: 125-131; http://dx.doi.org/10.3750/AIP2010.40.1.05

Fraser, D.J. (2008). How well can captive breeding programs conserve biodiversity? A review of salmonids. Evolutionary Applications. 11-1(4): 535-586; http://dx.doi.org/10.1111/j.17524571.2008.00036.x

Gilderhus, P.A. (1990). Benzocaine as a fish aneshetic: efficacy and safety for spawning phase salmon. Progressive Fish Culturist 52(3): 189-191; http://dx.doi.org/10.1577/15488640(1990)052<0189:BAAFAE>2.3.CO;2

Gilderhus, P.A. \& L.L. Marking (1987). Comparative efficacy of 16 anesthetic chemicals on rainbow trout. North American Journal of Fisheries Management 7: 288-292.

Gullian, M. \& J. Villanueva (2009). Efficacy of tricaine methanesulphonate and clove oil as anaesthetics for juvenile cobia, Rachycentron canadum. Aquaculture Research 40: 852-860; http:// dx.doi.org/10.1111/j.1365-2109.2009.02180.x

Hajek, G.J. \& B. Klyszejko (2004). The effects of Propiscin (etomidate) on the behaviour, heart rate, and ventilation of common carp, Cyprinus carpio L. Acta Ichthyologica et Piscatoria 34: 129-143; http://dx.doi.org/10.3750/AIP2010.40.1.05

Hajek, G.J., B. Klyszejko \& R. Dziaman (2006). The anaesthetic effect of clove oil on common carp, Cyprinus carpio L. Acta Ichthyologica et Piscatoria 36: 93-97.

Harms, C.A. (1999). Anesthesia in fish, pp. 158-163. In: Fowler, M.E. \& R.E. Miller (eds.). Zoo and Wild Animal Medicine, Current Therapy 4. WB Saunders, Philadelphia

Heo, G.J. \& G. Shin (2010). Efficacy of benzocaine as an anaesthetic for Crucian Carp (Carassius carassius). Veterinary Anaesthesia and Analgesia 37: 132-135; http://dx.doi.org/10.1111/j.14672995.2009.00510.x

Hicks, B. (1989). Anaesthetics: sweet dreams for fragile fish. Canadian Aquaculture 89: 29-31.

Hseu, J.R., S.L. Yeh, Y.T. Chu \& Y.Y. Ting (1998). Comparison of efficacy of five anaesthetic Gold-lined Sea Bream, Sparus sarba. Acta Zoologica et Taiwanica 9: 35-41.

Inoue, L.A.K.A., N.C. Santos-Neto \& G. Moraes (2003). Clove oil as anesthetic for juveniles of matrinxa, Brycon cephalus (Gunther, 1869). Cilncia Rural 33: 943-947; http://dx.doi.org/10.1590/S004459672005000200018

Iversen, M., B. Finstad., R.S. MacKinley \& R.A. Eliassen (2003) The efficacy of metomidate, clove oil, Aqui-S ${ }^{\mathrm{TM}}$ and Benzoak ${ }^{\circledR}$ as anaesthetics in Atlantic salmon (Salmo salar L.) smolts, and their potential stress-reducing capacity. Aquaculture 221: 549-566; http://dx.doi.org/10.1016/S0044-8486(03)00111-X

Iwama, G.K., A.D. Pickering, J.P. Sumpter \& C.B. Schreck (1997). Fish Stress and Health in Aquaculture. Cambridge University Press, UK, 278pp.

King, W.V., B. Hooper, S. Hillsgrove, C. Benton \& D. Berlinsky (2005). The use of clove oil, metomidate, tricaine, methanesulphonate and PE for inducing anaesthesia and their effect on the cortisol stress response in Black Sea Bass (Centropristis striata L.) Aquaculture Research 36: 1442-1449; http://dx.doi.org/10.1111/j.13652109.2005.01365.x

Marking, L.L \& F.P. Meyer (1985). A better fish anaesthetics needed in fisheries. Fisheries 10(6): 2-5.

Maren, T.H., R. Embry \& L.E. Broder (1968). The excretion of drugs across the gill of the Dog Fish, Squalus acanthias. Comparative 
Biochemistry and Physiology 26: 853-864; http://dx.doi. org/10.1016/0010-406X (68)90004-2

Mattson, N.S. \& T.H. Riple (1989). Metomidate, a better anaesthetic for Cod (Gadus morhua) in comparison with benzocaine, MS-222, chlorobutanol and phenoxyethanol. Aquaculture 83: 89-94; http:// dx.doi.org/10.1016/0044-8486 (89)90063-X

Mercy, T.V.A. (2009). Status of standardized breeding and propagation technology of indigenous ornamental fishes of Western Ghats of India. Journal of World Aquaculture 35(4): 40-42.

Mercy, T.V.A., V. Malika \& S. Sajan (2010). Breakthrough in breeding of Puntius denisonii. Info Fish International 3(4): 14-17.

Mylonas, C.C., G. Cardinaletti, I. Sigelaki \& A. Polzonetti-Magni (2005). Comparative efficacy of clove oil and 2-phenoxyethanol as anaesthetics in the aquaculture of European Sea Bass (Dicentrarchus labrax) and Gilthead Sea Bream (Sparus aurata) at different temperatures. Aquaculture 246: 467-481; http://dx.doi. org/10.1016/j.aquaculture.2005.02.046

Pawar, H.B., S.V. Sanaye, R.A. Sreepada, V. Harish, U. Suryavanshi, Tanu \& Z.A. Ansari (2011). Comparison of efficacy of four anaesthetic agents in the Yellow Seahorse, Hippocampus kuda (Bleeker, 1852) Aquaculture 311(1-4): 155-161; http://dx.doi.org/10.1016/j. aquaculture.2010.12.007

Pramod, P.K., A. Ramachandran, T.P. Sajeevan, S. Thampy \& S.S. Pai (2010). Comparative efficacy of MS-222 and benzocaine as anaesthetics under simulated transport conditions of a tropical ornamental fish Puntius filamentosus (Valenciennes). Aquaculture Research 41: 309-314; http://dx.doi.org/10.1111/j.13652109.2009.02333.x

Ramachandran, A., M. Sekharan \& P.K. Pramod (2005). Freshwater ornamental fishes of Kerala, India their potential and captive survival in aquaria. In $7^{\text {th }}$ Asian Fisheries Forum. 30 November to 2 December 2003, Penang, Malaysia. (Abstracts).

Ross, L.G \& B. Ross (1999). Anesthetic and Sedative Techniques for Aquatic Animals. Institute of Aquaculture, University of Stirling. 58: 145-155.

Roubach, R., L.C. Gomes \& A.L. Val (2001). Safest level of tricaine methanesulfonate (MS-222) to induce anesthesia in juveniles of matrinxa, Bryconcephalus. Acta Amazonica 31: 159-163.

Sajan, S., T.V.A. Mercy \& V. Malika (2011). Successful captive breeding, early embryonic and larval development of Puntius denisonii (Day, 1865) (Osteichthyes: Cyprinidae) - an endemic ornamental barb of the Western Ghats hotspot of India. In: Asian - Pacific Aquaculture \& Giant Prawn 2011. World Aquaculture Society, 18-20 January 2011, Kochi, India.

Sajan, S., T.V.A. Mercy \& V. Malika (2012). Use of an eco-friendly anaesthetic in the handling of Puntius denisonii (Day, 1865) - an endemic ornamental barb of the Western Ghats of India. Indian Journal of Fisheries 59(3): 131-135.

Sladky, K.K., C.R. Swanson, M.K. Stoskopf, M.R. Loomis \& G. Lewbart (2001). Comparative efficacy of tricaine methanesulfonate and clove oil for use as anesthetics in Red Pacu (Piaractus brachypomus). American Journal of Veterinary Research 62(3): 337-342; http:// dx.doi.org/10.2460/ajvr.2001.62.337

Summerfelt, R.C \& L.S. Smith (1990). Anaesthesia, surgery and related techniques, pp. 213-272. In: Scherelk, C.B. \& P.B. Moyle (eds.). Methods for Fish Biology. American Fisheries Society, Bethesda, Maryland.

Sylvester, J.R. \& L.E. Holland (1982). Influence of temperature, water hardness, and stocking density on MS-222 response in three species of fish. Progressive Fish-Culturist 44(3): 138-141; http://dx.doi. org/10.1577/1548-8659(1982)44[138:IOTWHA]2.0.CO;2

Tytler, P \& A.D. Hawkins (1981). Vivisection, anaesthetics and minor surgery, pp. 247-278. In: Hawkins A.D. (ed.). Aquarium Systems. Academic Press, New York, NY, USA.

Walsh, C.T. \& B.C. Pease (2002). The use of clove oil as an anaesthetic for the Long-finned Eel, Anguilla reinhardtii Staindachener. Aquaculture Research 33: 627-635; http://dx.doi.org/10.1046/ j.1365-2109.2002.00701.x

Weber, R.A., J.B. Peleteiro, L.O. García-Martín \& M. Aldegunde (2009). The efficacy of 2-phenoxyethanol, metomidate, clove oil and MS-222 as anaesthetic agents in the Senegalese Sole (Solea senegalensis Kaup, 1858). Aquaculture 288: 147-150; http://dx.doi. org/10.1016/j.aquaculture.2008.11.024

Weyl, O., H. Kaiser \& T. Hecht (1996). On the efficacy and mode of action of 2-phenoxyethanol as an anaesthetic for Goldfish, Carassius auratus (L.) at different temperatures and concentrations. Aquaculture Research 27(10): 757-764; http://dx.doi. org/10.1046/j.1365-2109.1996.t01-1-00791.x

Woody, C.A., J. Nelson \& K. Ramstad (2002). Clove oil as an anaesthetic for adult Sockeye Salmon: field trials. Journal of Fish Biology 60: 340347. http://dx.doi.org/10.1111/j.1095-8649.2002.tb00284.x 